\title{
Involvement of Fas Receptor and Not Tumor Necrosis Factor- $\alpha$ Receptor in Ultraviolet-Induced Activation of Acid Sphingomyelinase
}

\author{
Madhumita Chatterjee and Shiyong Wu* \\ Department of Radiation Oncology, Division of Radiation and Cancer Biology, University of Michigan Medical School, \\ Ann Arbor, Michigan
}

Fas receptor and tumor necrosis factor receptor-1 (TNFR1) mediate the activation of acid sphingomyelinase (ASMase), which catalyzes the hydrolysis of sphingomyelin to ceramide. Ceramide acts as a second messenger in mediating cell growth, differentiation, stress response, and apoptosis. Ultraviolet (UV) irradiation induces Fas receptor and TNFR1 aggregation. However, the roles of Fas receptor and TNFR1 in mediating UV-induced ASMase activation have not been explored. In this report, we demonstrate that Fas receptor, not TNFR1, mediated UV-induced activation of ASMase. Our data indicate that ASMase activity was not induced with UV irradiation but by TNF $\alpha$ in MCF-7 cells that expressed low levels of Fas receptor. In contrast, ASMase was activated by UV irradiation or TNF $\alpha$ treatment in Fas stably transfected MCF-7 cells. Immunofluorescence staining of TNFR1 on MCF-7 cells showed that TNFR1 was aggregated after treatment with UV irradiation or TNF $\alpha$. However, UV-induced aggregation of TNFR1 did not lead to induction of ASMase activity. These results suggest that Fas receptor aggregation is solely responsible for UV-induced activation of ASMase. Further, with the use of BJAB and dominant-negative Fas-associated death domain-containing protein (FADD) stably transfected BJAB cells, we demonstrated that dominant-negative FADD partly inhibited UVinduced ASMase activation. Our results suggest that FADD is involved in UV-induced and Fas-mediated signaling pathways for activation of ASMase. Mol. Carcinog. 30:47-55, 2001. () 2001 Wiley-Liss, Inc.

Key words: ultraviolet light; acid sphingomyelinase; Fas receptor; tumor necrosis factor $\alpha$ receptor; Fas-associated death domain-containing protein

\section{INTRODUCTION}

Sphingolipids are constituents of all eukaryotic cell membranes and play important roles in cell regulation and transmembrane signaling [1,2]. Sphingomyelin, the major membrane sphingolipid, can be hydrolyzed by sphingomyelinase to form ceramide. This process occurs in response to various agonists including Fas receptor (Fas; CD95 and Apo1) [3], ultraviolet (UV) light [4,5], tumor necrosis factor- $\alpha(\mathrm{TNF} \alpha)[6,7], \gamma$-interferon [6], interleukin-1 $\beta$ [8], nerve growth factor [9], ionizing radiation [10], and vitamin D3 [11]. Ceramide is involved in a novel signal transduction pathway in mammalian cells and serves as a lipid secondary messenger [1215]. The regulatory functions of ceramide include induction of retinoblastoma protein, which mediates the effects of ceramide on cell-cycle arrest [16], and activation of interleukin-1 $\beta$-converting enzymelike proteases, which mediate effects of ceramide on programmed cell death [17]. Ceramide regulates the mitogen-activated protein kinase cascade [18], induction of $\mathrm{I} \kappa \mathrm{B} \alpha$ degradation, and nuclear translocation of nuclear factor- $\kappa \mathrm{B}[19]$. Ceramide also participates in crucial cellular processes such as differentiation [11], proliferation [20], and apoptosis $[21,22]$. At least two sphingomyelinases, acid sphingomyelinase (ASMase) and neutral sphingo- myelinase (NSMase), have been described in mammalian cells $[23,24]$. NSMase is a plasma membranebound enzyme, and the optimum $\mathrm{pH}$ for NSMase activity is approximately 7.4 [25]. ASMase is a lysosomal hydrolase that resides in the endosomallysosomal compartment, with an optimum $\mathrm{pH}$ of approximately $5.0 \quad[26,27]$. The activity of this enzyme is deficient in Niemann-Pick disease, an inherited disorder characterized by accumulation of sphingomyelin [28]. Fas or tumor necrosis factor receptor-1 (TNFR1), which belongs to the tumor necrosis factor receptor superfamily [29], may mediate activation of ASMase [1,2]. Fas-associated death domain-containing protein (FADD), a com-

*Correspondence to: Department of Radiation Oncology, Division of Radiation and Cancer Biology, Room 4131, University of Michigan Medical School, 1331 E. Ann Street, Ann Arbor, MI 48109.

Received 10 July 2000; Revised 12 October 2000; Accepted 19 October 2000

Abbreviations: Fas, Fas receptor; UV, ultraviolet; TNF $\alpha$, tumor necrosis factor- $\alpha$; ASMase, acid sphingomyelinase; NSMase, neutral sphingomyelinase; TNFR1, TNF receptor-1; FADD, Fas-associated death domain-containing protein; MCF-7-Fas, Fas stably transfected MCF-7 cell line; DN, dominant negative; UVC, ultraviolet light, $254 \mathrm{~nm}$; DN-FADD-BJAB, DN-FADD stably transfected BJAB cell line; PBS, phosphate-buffered saline; IgG, immunoglobulin G; SDS-PAGE, sodium dodecyl sulfate-polyacrylamide gel electrophoresis. 
mon mediator of Fas- and TNF $\alpha$-induced apoptosis, is involved in TNFR1-mediated ASMase activation signaling pathways. TNF $\alpha$ induces aggregation of TNFR1, which then binds an adaptor protein, TNFR1-associated protein with death domain, that in turn recruits and activates FADD. The activated FADD then mediates the activation of ASMase by activating caspases distinct from caspase-8 [2]. Previous reports have indicated that Fas activates ASMase with caspase-8 [30]. However, no direct evidence for the involvement of FADD in UVmediated activation of ASMase is known. Exposure of mammalian cells to UV radiation activates ASMase, which plays an important role in UVinduced signal transduction $[4,31]$. UV irradiation also induces aggregation of the cell-surface receptors, including Fas and TNFR1 [32,33]. However, the relation between UV-induced aggregation of the receptors and ASMase activation is not known. The molecular mechanism of UV-induced activation of ASMase remains unclear. In this article, we provide evidence that UV-induced ASMase activation is mediated only by Fas aggregation. In addition, FADD is involved in the activation of ASMase with UV irradiation.

\section{MATERIALS AND METHODS}

\section{Cell Culture}

MCF-7 cells were cultured in RPMI-1640 containing 10\% fetal calf serum, 2 mM L-glutamine, $100 \mathrm{U} /$ $\mathrm{mL}$ penicillin, and $100 \mu \mathrm{g} / \mathrm{mL}$ streptomycin at $37^{\circ} \mathrm{C}$ in an atmosphere of $5 \% \mathrm{CO}_{2}$. Fas stably transfected MCF-7 (MCF-7-Fas) cells and dominant-negative (DN) FADD stably transfected BJAB (DN-FADD$\mathrm{BJAB}$ ) cells were kindly provided by Dr. Alnawaz Rehemtulla (University of Michigan Medical School). MCF-7-Fas cells were maintained in the same medium containing $0.5 \mathrm{mg} / \mathrm{mL}$ G418. DN-FADD$\mathrm{BJAB}$ cells were maintained in the same RPMI medium containing $1 \mathrm{mg} / \mathrm{mL}$ G418. All culture media, sera, antibiotics, and amino acids were obtained from Life Technologies (Gaitherburg, MD) unless otherwise noted.

\section{UV Irradiation}

Cells were irradiated with UV at $254 \mathrm{~nm}$ (UVC) with a germicidal lamp. The intensity of UVC was standardized with a UV meter (UVP Inc., Upland, CA). For low-dose $\left(<100 \mathrm{~J} / \mathrm{m}^{2}\right)$ UV irradiation, the intensity of UVC was set at $1.5 \mathrm{~W} / \mathrm{m}^{2}$. For high-dose $\left(100 \mathrm{~J} / \mathrm{m}^{2}\right) \mathrm{UV}$ irradiation, the intensity of UVC was set at $3.0 \mathrm{~W} / \mathrm{m}^{2}$. Adherent cells $(70-80 \%$ confluent on $60-\mathrm{mm}$ plates) were irradiated with $200 \mu \mathrm{L}$ of culture medium. Cells in suspension $\left(1.5 \times 10^{7}\right)$ were pelleted, resuspended in $0.5 \mathrm{~mL}$ of medium, and plated on $60-\mathrm{mm}$ plates for irradiation. After UV irradiation, $3 \mathrm{~mL}$ of medium was added to each 60-mm plate.

\section{Immunofluorescence Staining}

Indirect immunofluorescence staining was performed as described previously [33]. Briefly, cells were seeded on microcoverslips (Fisher Scientific, Pittsburgh, PA) coated with 1\% gelatin. After 24 h, the cells were exposed to UV radiation or treated with TNF $\alpha$ (Sigma Chemicals, St Louis, MO), washed twice with phosphate-buffered saline (PBS), and fixed in $4.0 \%$ paraformaldehyde. Cells were then incubated with monoclonal anti-TNFR1 antibodies (H-5, Santa Cruz Biotechnologies, Santa Cruz, CA) at a 1:50 dilution in PBS for $1 \mathrm{~h}$ at room temperature. Rhodamine-conjugated goat anti-mouse immunoglobulin G (IgG; Pierce, Rockford, IL) was used as a secondary antibody, and photographs were taken with a camera mounted on a Zeiss fluorescence microscope.

\section{Western Blot Analysis}

Cells were harvested and lysed with lysing buffer (2\% NP-40, $80 \mathrm{mM} \mathrm{NaCl}, 100 \mathrm{mM}$ Tris- $\mathrm{HCl}$, and 0.1\% sodium dodecyl sulfate) containing $1 \times$ Complete protease inhibitor cocktail (Roche Molecular Biochemicals, Indianapolis, IN). After centrifugation at $14000 \mathrm{rpm}$ for $10 \mathrm{~min}$, supernatant fractions were collected, and the protein concentration was measured with the Bio-Rad protein assay kit (Bio-Rad Laboratories, Hercules, CA). Equal amounts of protein samples were subjected to sodium dodecyl sulfate-polyacrylamide gel electrophoresis (SDSPAGE) and electroblotted to nitrocellulose membranes. Membranes were probed with a rabbit polyclonal antibody against Fas or a mouse monoclonal antibody against TNFR1 (both from Santa Cruz Biotechnologies). After extensive washing with PBS, membranes were incubated with correlated horseradish peroxidase-conjugated secondary antibodies. Signals were detected with a SuperSignal Chemiluminescent kit according to the manufacturer's instructions (Pierce).

\section{Assay for ASMase}

Cells were harvested and washed twice with icecold PBS. To measure ASMase activity, cell pellets were resuspended in Triton lysis buffer $(250 \mathrm{mM}$ sodium acetate, $1 \mathrm{mM}$ EDTA, $\mathrm{pH} 5$, and $0.2 \%$ Triton$X$ 100) and sonicated. Cell debris was removed by centrifugation at $3000 \times g$ at $4^{\circ} \mathrm{C}$. From the supernatant fractions, $100 \mu \mathrm{g}$ of protein was incubated for $2 \mathrm{~h}$ at $37^{\circ} \mathrm{C}$ in an ASMase assay buffer $(50 \mu \mathrm{L}$ final volume) containing $250 \mathrm{mM}$ sodium acetate, 1 mM EDTA, (pH 5), and $2 \mu \mathrm{L}$ of choline-methyl ${ }^{14} \mathrm{C}$ sphingomyeline $(0.02 \mathrm{mCi} / \mathrm{mL}$; NEN, Boston, MA). Phosphorylcholine was then extracted with $800 \mu \mathrm{L}$ of chloroform:methanol $(2: 1, \mathrm{v} / \mathrm{v})$ and $250 \mu \mathrm{L}$ of $\mathrm{H}_{2} \mathrm{O}$. Radioactive phosphorylcholine was determined in the aqueous phase by liquid scintillation counting. 


\section{RESULTS}

Inhibition of UV-Induced ASMase Activation in MCF-7 Cells

UV irradiation activates ASMase in many mammalian cells [4], but our data show that UV irradiation failed to induce ASMase activity in MCF-7 cells (Figure 1A) but did induce ASMase activation in 293 cells (170\%; Figure 1A) and BJAB cells (300\%; Figure 1A). The time-dependent assay of ASMase activity indicated that ASMase activity increased slightly within 5 min of UV irradiation and then steadily decreased in MCF-7 cells (Figure 1B). These results suggest that, unlike in 293 or BJAB cells, the signaling pathways involved in UVinduced ASMase activation in MCF-7 cells are defective. Previous reports have indicated that Fas

A)

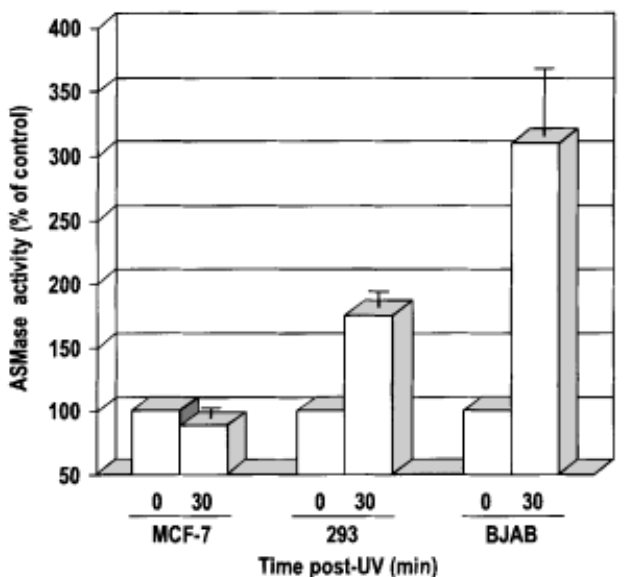

B)

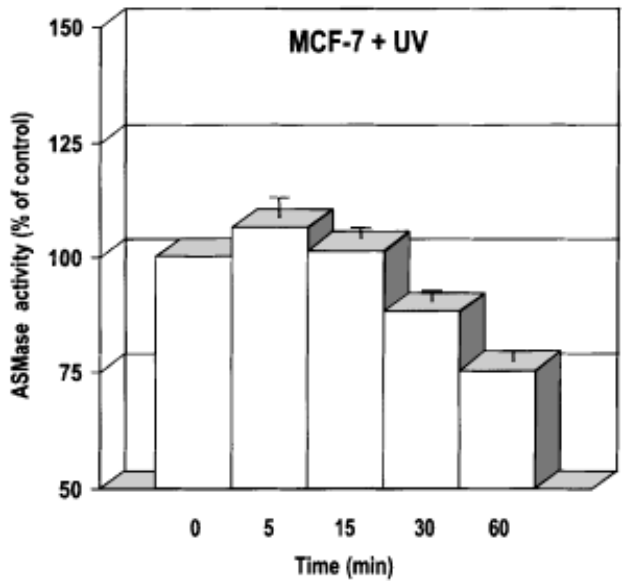

Figure 1. UV irradiation induced ASMase activity in 293 and BJAB cells but not in MCF-7 cells. Cells were UV irradiated, and the ASMase activities in the cells were determined by using the method described in Materials and Methods. ASMase activities are expressed as percentages of untreated cells. (A) MCF-7, 293, and BJAB cells were irradiated with 0 and $100 \mathrm{~J} / \mathrm{m}^{2}$ UVC. ASMase activities were measured $30 \mathrm{~min}$ after irradiation. (B) MCF-7 cells were irradiated with 0 and $100 \mathrm{~J} / \mathrm{m}^{2}$ UVC. ASMase activities were determined 5, 15, 30 , and $60 \mathrm{~min}$ after irradiation.
A)

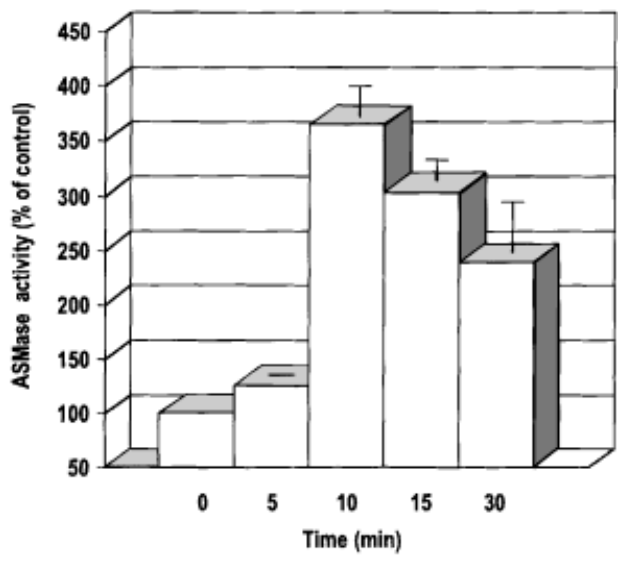

MCF-7

B)

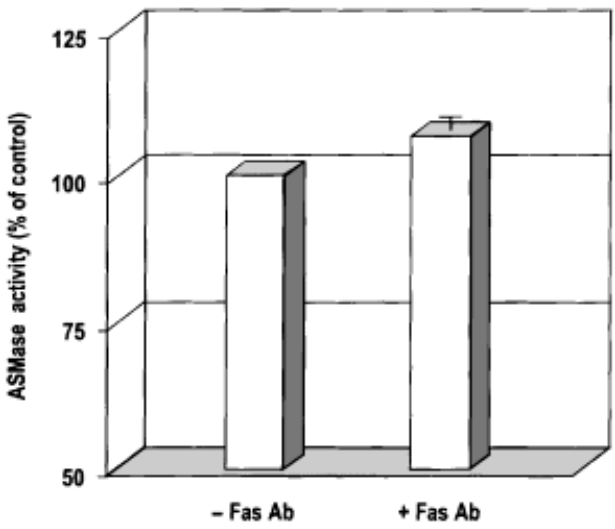

Figure 2. TNF $\alpha$, but not anti-Fas antibody, induced activation of ASMase in MCF-7 cells. TNF $\alpha$ - and anti-Fas antibody-treated MCF-7 cells were lysed, and the ASMase activities in cellular lysates were analyzed. ASMase activities are expressed as percentages of untreated control cells. (A) MCF-7 cells were treated with $25 \mathrm{ng} /$ $\mathrm{mL}$ TNF $\alpha$ (Sigma Chemical Co., St. Louis, MO). The cellular lysates were then prepared after $5,10,15$, and 30 min of TNF $\alpha$ treatment. (B) MCF-7 cells were treated with $0.1 \mu \mathrm{g} / \mathrm{mL}$ of a rabbit anti-Fas polyclonal antibody (N-18, Santa Cruz Biotechnologies, Santa Cruz, CA) for $2 \mathrm{~h}$ before the cells were lysed for the ASMase activity assay.

and TNFR1 mediate ASMase activation with Fas antibody and TNF $\alpha$ treatments $[1,34]$. Because UV irradiation induced aggregation of both receptors, we next evaluated the effect of Fas antibody and $\mathrm{TNF} \alpha$ on ASMase activation in MCF-7 cells. A $260 \%$ induction of ASMase activity in MCF-7 cells was observed within $10 \mathrm{~min}$ of $\mathrm{TNF} \alpha$ treatment (Figure 2A), whereas anti-Fas-antibody treatment induced ASMase activity by only $15 \%$ in the same cells (Figure 2B). This was similar to the ASMase activity increase after UV irradiation (Figure 1B). These results suggest that the TNFR1-mediated ASMase activation pathway is intact but that the Fasinduced ASMase activation pathway is defective in MCF-7 cells. 
TNFR1 Aggregation in MCF-7 Cells After UV Irradiation and TNF $\alpha$ Treatment

Because the TNF $\alpha$-mediated ASMase activation signaling pathway was intact in MCF-7 cells, we examined whether UV irradiation failed to induce TNFR1 aggregation in MCF-7 cells. TNFR1 aggregation after TNF $\alpha$ treatment or UV irradiation was monitored with the immunofluorescence staining method described in Materials and Methods. Our data show that immunostaining patterns for TNF $\alpha$ treated and UV-irradiated cells displayed similar TNFR1 aggregation patterns that were different from the diffuse pattern of untreated cells (Figure 3B and $C$ vs. A). TNF $\alpha$-treated and UV-irradiated cells exhibited intense clustered TNFR1-specific immunostaining that was detectable predominantly at the cell peripheral margins (Figure 3, arrows). This type of staining pattern may reflect TNFR1 aggregation [33]. These results indicate that UV irradiation promotes TNFR1 aggregation in MCF-7 cells comparable to that induced by TNF $\alpha$. However, UVinduced aggregation of $\mathrm{TNF} \alpha$ did not lead to activation of ASMase as TNF $\alpha$ did. Our results suggest that $\mathrm{UV}$-induced ASMase activation is not mediated by TNFR1.

Role of Fas Receptor in UV-Induced Activation of ASMase

Because our results suggested that TNFR1 is not involved in UV-induced ASMase activation, we investigated whether the lack of sensitivity to UVinduced activation of ASMase is due to a defective Fas-mediated signaling pathway or to the low expression of Fas in MCF-7 cells, which was reported previously [35]. To determine whether Fas in MCF-7 cells is responsible for ASMase activation with UV irradiation, we examined ASMase activity in MCF-7Fas cells after UV irradiation. MCF-7-Fas cells showed a 100\% increase in ASMase activity after 30 min of UV irradiation (Figure 4A), which was comparable to that observed in 293 cells and $\mathrm{BJAB}$ cells (Figure 1A). Our results suggest that low-level Fas expression causes unresponsiveness of ASMase after UV irradiation. Our data also suggest that Fas is responsible for UV-induced activation of ASMase because restoration of ASMase responsiveness was obtained in MCF-7-Fas cells.

To confirm that overexpression of Fas corrected the Fas-induced ASMase activation pathway, we examined whether anti-Fas antibody activates ASMase in MCF-7-Fas cells. Our data indicate that, with the overexpression of Fas, MCF-7 cells became sensitive to anti-Fas antibody for ASMase activation (Figure 4C). An approximately $150 \%$ increase in ASMase activity was observed in MCF-7-Fas cells after anti-Fas-antibody treatment (Figure 4C). TNF $\alpha$ treatment resulted in a $215 \%$ increase in ASMase activity in MCF-7-Fas cells (Figure 4B), similar to the inducibility of ASMase activity in MCF-7 cells (Figure 2A). An interesting observation was that, although inducibility of ASMase with TNF $\alpha$ treat-
A)

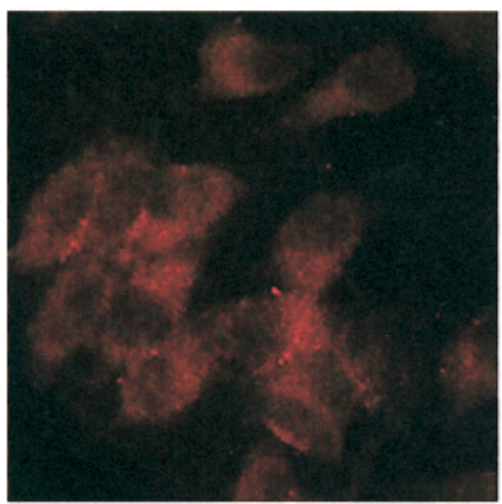

Control

(untreated)
B)

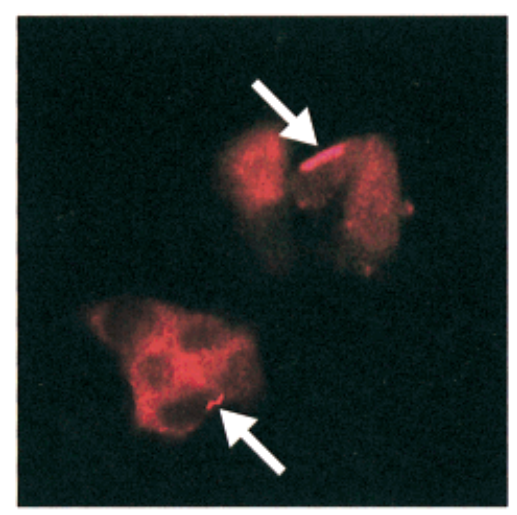

TNF $\alpha$-treated

$(25 \mathrm{ng} / \mathrm{ml})$
C)

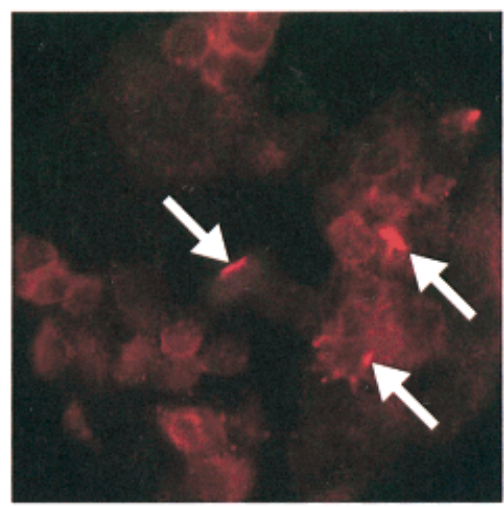

UV-irradiated $\left(30 \mathrm{~J} / \mathrm{m}^{2}\right)$
Figure 3. UV irradiation induced aggregation of TNFR1 in MCF-7 cells in the same way as TNF $\alpha$. MCF-7 cells were seeded on microcoverslips coated with $1 \%$ gelatin $24 \mathrm{~h}$ before treatment. The cells were then left untreated $(A)$, treated with TNF $\alpha(25 \mathrm{ng} / \mathrm{mL}, 15$ $\mathrm{min} ; \mathrm{B})$, or exposed to UV radiation $\left(30 \mathrm{~J} / \mathrm{m}^{2}, 30 \mathrm{~min} ; \mathrm{C}\right)$. The cells were fixed in $4.0 \%$ paraformaldehyde for $30 \mathrm{~min}$ and then incubated with $4 \mu \mathrm{g} / \mathrm{mL}$ mouse anti-TNFR1 monoclonal antibody ( $\mathrm{H}-5$, Santa Cruz Biotechnologies) for $1 \mathrm{~h}$ at room temperature. Rhodamineconjugated goat anti-mouse IgG was used as a secondary antibody, and photographs were taken using a camera mounted on a Zeiss fluorescence microscope. Arrows indicate the aggregated form of TNFR1. 
A)

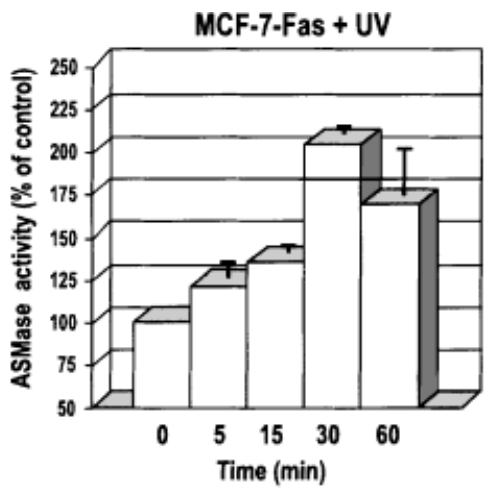

B)

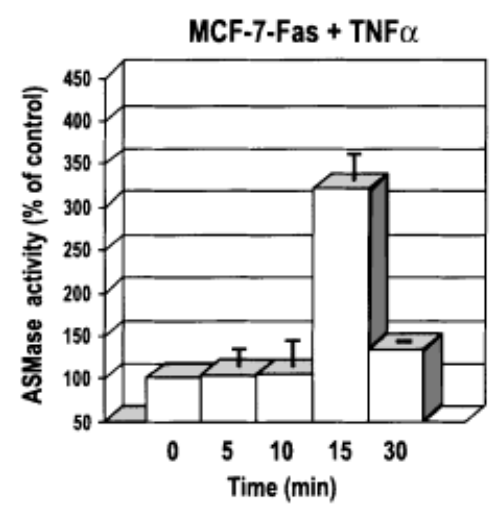

C)

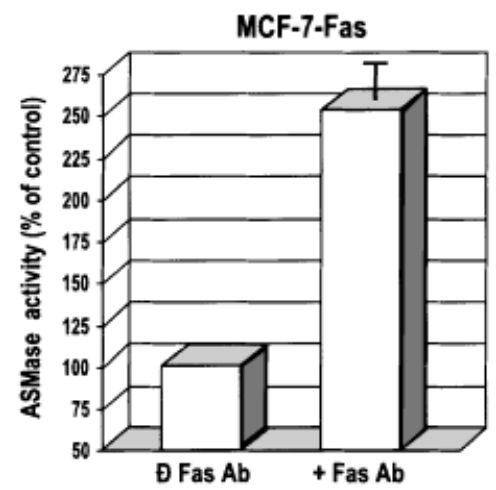

Figure 4. ASMase activity increased in MCF-7-Fas cells in response to UV irradiation, TNF $\alpha$, or anti-Fas antibody. MCF-7-Fas cells were treated with different stimuli, and then ASMase activities were analyzed. ASMase activities are expressed as percentages of untreated control cells. (A) MCF-7-Fas cells were irradiated with 0 and $100 \mathrm{~J} / \mathrm{m}^{2}$ UVC. ASMase activities were determined 5, 15, 30, and 60 min after irradiation. (B) MCF-7-Fas cells were treated with 25 $\mathrm{ng} / \mathrm{mL}$ TNF $\alpha$. After $5,10,15$, and 30 min of TNF $\alpha$ treatment, ASMase activity in cellular lysates was examined. (C) MCF-7-Fas cells were treated with $0.1 \mu \mathrm{g} / \mathrm{mL}$ mouse anti-Fas monoclonal antibody for $2 \mathrm{~h}$ before analysis of ASMase activity.

ment did not significantly change with overexpression of Fas, the peak time of ASMase activity was shifted and shortened. These results suggest that Fas and TNFR1 may interfere with each other's aggregation in response to various stimuli. In addition to determining the ASMase activities, we examined the expression level of Fas and TNFR1 in MCF-7 and MCF-7-Fas cells by using western blot analysis. Our data show that there was an undetectable amount of Fas in MCF-7 when compared with the higher level of expression of Fas in MCF-7-Fas cells (Figure 5A). However, the immunoblot analysis of TNFR1 showed an equivalent level of TNFR1 in MCF-7 and MCF-7-Fas cells (Figure 5B). These results suggest that UV-induced activation of ASMase in MCF-7-Fas cells is caused by increased expression of Fas.

Involvement of FADD in UV-Induced

Activation of ASMase

Because FADD is reportedly involved in $\mathrm{TNF} \alpha$ induced activation of ASMase [36], we examined whether it is also involved in UV-induced activation of ASMase. BJAB and DN-FADD-BJAB cells were used in the experiments. Both cell lines were exposed to $\mathrm{TNF} \alpha$ or UV radiation for different periods (Figure 6). Our data show that BJAB cells had $160 \%$ and $200 \%$ increases in ASMase activity after TNF $\alpha$ treatment and UV irradiation, respectively (Figure 6A and $\mathrm{B})$. However, in DN-FADD-BJAB cells, TNF $\alpha$ induced activation of ASMase produced a 30\% increase (Figure 6A). These data are in agreement with previous observations that FADD is responsible for $\mathrm{TNF} \alpha$-mediated activation of ASMase [36]. UVinduced activation of ASMase produced a $40 \%$ increase (Figure 6B). These results suggest that FADD is also involved in UV-induced activation of ASMase.

To exclude the possibility that the lack of inducibility of ASMase with UV irradiation in DNFADD-BJAB cells was caused by the lack of Fas expression, we analyzed Fas expression levels in 293, $\mathrm{BJAB}$, and DN-FADD-BJAB cell lines before and after UV irradiation. Our data indicate that Fas expression was not decreased in DN-FADD-BJAB cells (Figure 7). Our data also show that UV irradiation did not induce Fas expression in these cell lines (Figure 7). Thus, UV-induced activation of ASMase seems to depend on the activation of Fas but does not induce Fas expression.

\section{DN-FADD Partly Inhibited Fas-Induced Activation of ASMase}

To confirm that overexpression of DN-FADD inhibited the Fas-induced ASMase activation pathway, we measured the ASMase activation in 293, $\mathrm{BJAB}$, and DN-FADD-BJAB cell lines after treatment with anti-Fas antibody. Our data show that the anti-Fas-antibody-induced activation of ASMase was reduced in DN-FADD-BJAB cells (Figure 8), which agrees with our hypothesis that UV-induced activation of ASMase occurs in the Fas signaling pathway.

\section{DISCUSSION}

Activation of ASMase plays a critical role in UVinduced JNK activation and apoptosis. However, 


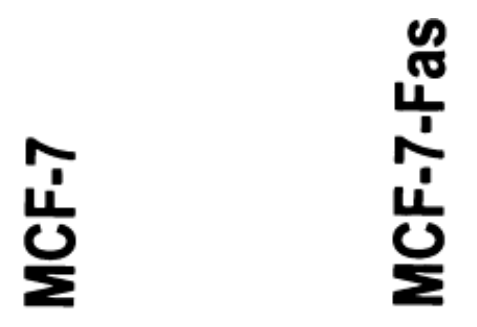

A)

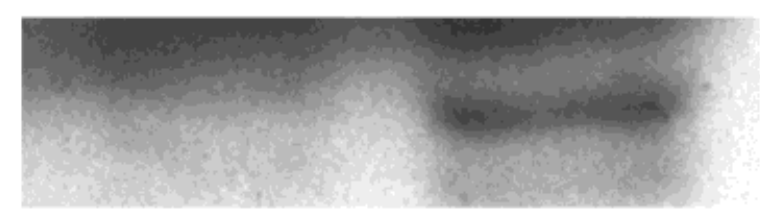

$\leftarrow$ Fas receptor

B)

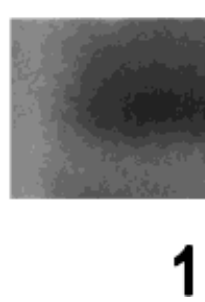

Figure 5. Expression levels of Fas receptor and TNFR1 in MCF-7 and MCF-7-Fas cells. Cellular lysates of MCF-7 and MCF-7-Fas cells were prepared as described in Materials and Methods. Equal amounts of protein $(40 \mu \mathrm{g})$ were subjected to SDS-PAGE and electroblotted to nitrocellulose membranes. The membranes were immunoblotted with a rabbit anti-Fas polyclonal antibody ( $\mathrm{N}-18$ Santa Cruz Biotechnologies) and a mouse anti-TNFR1 monoclonal

very little is known about how UV irradiation activates ASMase. In this study, we delineated the role of Fas and TNFR1 in UV-induced activation of ASMase. Five cell lines (MCF-7, MCF-7-Fas, 293, $\mathrm{BJAB}$, and DN-FADD-BJAB) were used in these studies. Relative basal activities of ASMase in these cell lines are shown in Figure 9. Because cells have a better response to UVC than to UVB, many UV signaling studies have used UVC [4,32]. We adapted this technique to establish our research model. Human breast cancer cell line MCF-7 had a basal ASMase activity, but no induction in ASMase activity was observed with UV irradiation. Treatment with anti-Fas antibody also did not increase ASMase activity. However, when the same cells were treated with TNF $\alpha$, an approximately $250 \%$ increase in ASMase activity was observed. These data support the notion that in MCF-7 cells the Fas-mediated ASMase activation pathway is defective, whereas the TNFR1-mediated ASMase activation pathway is intact. Previous reports have provided evidence that UV irradiation results in the aggregation of Fas and TNFR1 [33]. Previous [36] and our present data also showed that TNF $\alpha$-induced TNFR1 aggregation activated ASMase. Because UV irradiation failed to induce ASMase activation as TNF $\alpha$ did in MCF-7 cells, we examined whether UV irradiation also failed to induce TNFR1 aggregation in MCF-7 cells. Our data indicate that UV did cause TNFR1 aggregation, and the immunostaining pattern was very similar to that caused by $\mathrm{TNF} \alpha$, suggesting that UV irradiation induces TNFR1 aggregation but does not lead to the activation of ASMase as TNF $\alpha$ does. Based on these findings, we propose that in MCF-7 cells TNFR1 is not involved in UV-induced activation of ASMase. As discussed earlier, neither UV irradiation nor anti-Fas-antibody treatment resulted in activation of ASMase. Therefore, to examine whether Fas is solely responsible for enhancement of ASMase activation with UV irradiation, we studied UVinduced ASMase activation in the MCF-7-Fas cell line. MCF-7-Fas cells showed an approximately $100 \%$ increase in ASMase activity when exposed to UV radiation. Immunoblot analysis indicated that Fas was expressed at a much higher level in MCF-7Fas cells, whereas TNFR1 expression was not altered in these cells. These results support the hypothesis that Fas aggregation is responsible for UV-induced activation of ASMase. Because TNF $\alpha$-mediated activation of ASMase is mediated by FADD [2], we then 
A)

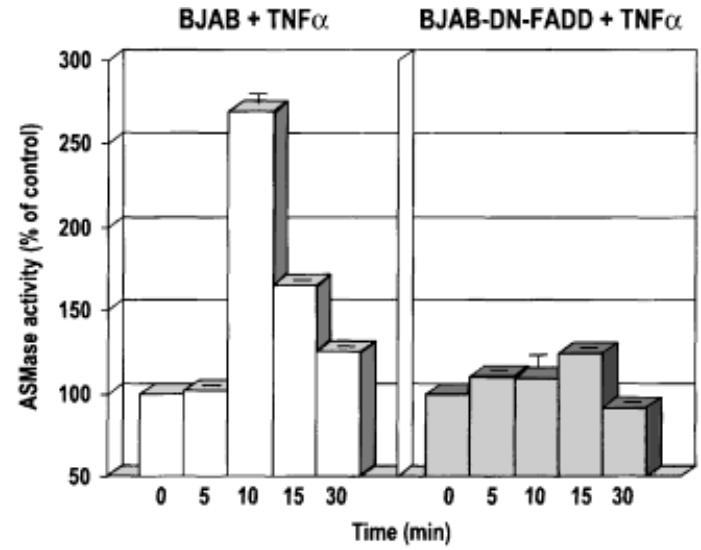

B)

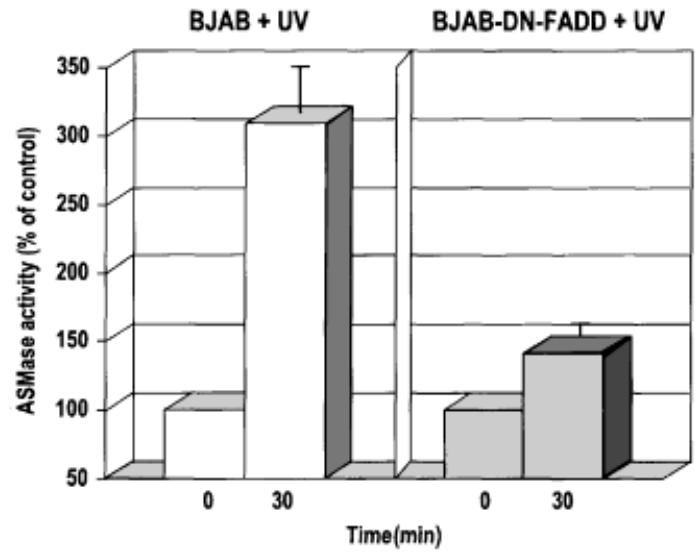

Figure 6. FADD mediated UV-induced ASMase activation. Wildtype BJAB and DN-FADD-BJAB cells were lysed after TNF $\alpha$ treatment or UV irradiation at the indicated times. ASMase activities in the cells were examined and are expressed as the percentage of untreated cells. (A) BJAB and DN-FADD-BJAB cells were treated with $25 \mathrm{ng} / \mathrm{mL}$ TNF $\alpha$. After $5,10,15$, and 30 min of TNF $\alpha$ treatment, cellular lysates were prepared and ASMase activities were measured. (B) BJAB and DN-FADD-BJAB cells were irradiated with 0 and $100 \mathrm{~J} / \mathrm{m}^{2}$ UVC ASMase activities were determined 30 min after irradiation.

examined whether FADD is also involved in UVinduced and Fas-mediated ASMase activation. We measured ASMase activities after UV irradiation in $\mathrm{BJAB}$ and DN-FADD-BJAB cell lines. In $\mathrm{BJAB}$ cells, ASMase activity increased $210 \%$ in response to UV

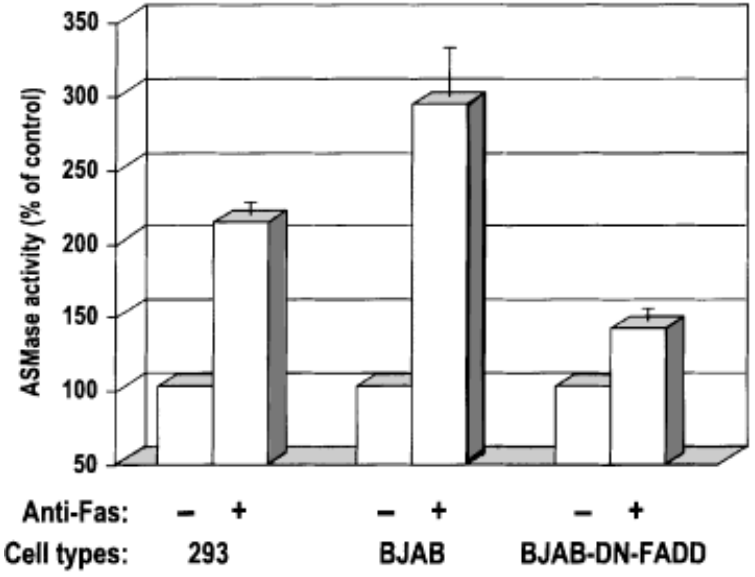

Figure 8. DN-FADD inhibited anti-Fas antibody-induced ASMase activation. 293, BJAB and DN-FADD-BJAB cells were untreated or treated with $0.1 \mu \mathrm{g} / \mathrm{mL}$ rabbit anti-Fas polyclonal antibody $(\mathrm{N}-18$, Santa Cruz Biotechnologies) for $2 \mathrm{~h}$ as indicated. The cells were then lysed, and the ASMase activity was analyzed as described in Materials and Methods.

irradiation; in DN-FADD-BJAB cells, ASMase activity increased only $45 \%$ after UV irradiation, indicating that FADD is required not only for TNF $\alpha$-induced activation of ASMase but also for UV-induced and Fas-mediated activation of ASMase.

In conclusion, we have shown that UV-induced ASMase activation was mediated by Fas, not TNFR1. After UV irradiation, Fas was aggregated and recruited FADD, which was involved in UV-and TNF $\alpha$-induced activation of ASMase. Together these results indicate that UV irradiation causes the aggregation of TNFR1 and Fas; however, only the aggregation of Fas leads to ASMase activation, whereas TNFR1 aggregation does not. A possible explanation for this observation could be that UV-induced TNFR1 aggregation results in the recruitment of an adaptor protein that is different from the adaptor protein recruited by $\mathrm{TNF} \alpha$-induced aggregation. If this is the case, the next challenge is to isolate and characterize the factors recruited by TNFR1 after UV irradiation and TNF $\alpha$ treatment. These studies may provide new approaches to induce apoptosis of UV-damaged

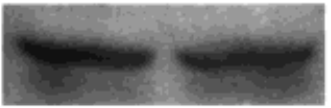

UV $\left(100 \mathrm{~J} / \mathrm{m}^{2}\right)$ : Cell types: 293

Figure 7. UV irradiation did not induce the expression of Fas. 293, $B J A B$, and DN-FADD-BJAB cells were irradiated with 0 or $100 \mathrm{~J} / \mathrm{m}^{2}$ UVC. Thirty minutes after irradiation, the cells were lysed with NP-40 lysis buffer. Total proteins $(50 \mu \mathrm{g})$ were loaded on SDS-PAGE gels, and electroblotted onto nitrocellulose membranes. The membranes
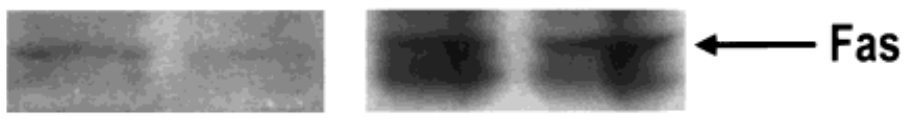

BJAB

BJAB-DN-FADD

were immunoblotted with a rabbit anti-Fas polyclonal antibody (N18, Santa Cruz Biotechnologies) and then probed with a horseradish peroxidase-conjugated anti-rabbit lgG antibody. Fas expression was visualized using the SuperSignal Chemiluminescent kit (Pierce) according to the manufacturer's procedure. 


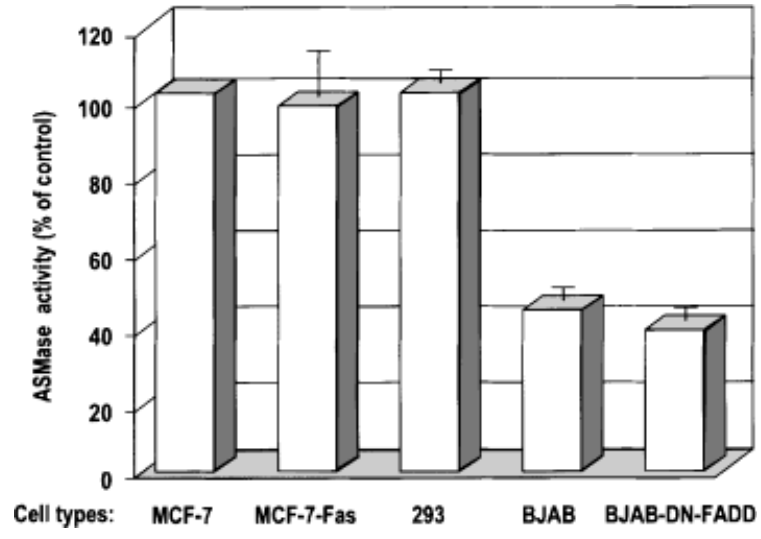

Figure 9. Relative activities of ASMase in the cell lines studied ASMase activities in MCF-7, MCF-7-Fas, 293, BJAB, and DN-FADD$B J A B$ cells were determined as described in Materials and Methods. Relative activities were calculated based on basal ASMase activity in MCF-7 cells.

cells that may prove useful in preventing and treating UV-related skin cancers.

\section{ACKNOWLEDGMENTS}

We thank Drs. Alnawaz Rehemtulla, Stephen Ethier, and Theodore Lawrence for providing cell lines and support. We also thank Dr. Mats Ljungman for critical reading of the article. We are greatly indebted to Amy Pace for her expertise in editing the figures. We also thank Dr. Neelam Taneja and Ju-Lin Wang for helping prepare pictures and reagents. Funding for this research was provided by the Department of Radiation Oncology, Division of Radiation and Cancer Biology, University of Michigan Medical School, Ann Arbor.

\section{REFERENCES}

1. Cifone MG, De Maria R, Roncaioli $P$, et al. Apoptotic signaling through CD95 (Fas/Apo-1) activates an acidic sphingomyelinase. J Exp Med 1994;180:1547-1552.

2. Schwandner R, Wiegmann K, Bernardo K, Kreder D, Kronke $M$. TNF receptor death domain-associated proteins TRADD and FADD signal activation of acid sphingomyelinase. J Biol Chem 1998;273:5916-5922.

3. Kolesnick RN, Kronke M. Regulation of ceramide production and apoptosis. Annu Rev Physiol 1998;60:643-665.

4. Verheij M, Bose R, Lin XH, et al. Requirement for ceramideinitiated SAPK/JNK signalling in stress-induced apoptosis. Nature 1996;380:75-79.

5. Strum JC, Small GW, Pauig SB, Daniel LW. 1-beta-DArabinofuranosylcytosine stimulates ceramide and diglyceride formation in HL-60 cells. J Biol Chem 1994;269:1549315497.

6. Kim MY, Linardic C, Obeid L, Hannun Y. Identification of sphingomyelin turnover as an effector mechanism for the action of tumor necrosis factor alpha and gamma-interferon. Specific role in cell differentiation. J Biol Chem 1991; 266:484-489.

7. Dressler KA, Mathias S, Kolesnick RN. Tumor necrosis factor-alpha activates the sphingomyelin signal transduction pathway in a cell-free system. Science 1992;255:17151718 .
8. Ballou LR, Chao CP, Holness MA, Barker SC, Raghow R. Interleukin-1-mediated PGE2 production and sphingomyelin metabolism. Evidence for the regulation of cyclooxygenase gene expression by sphingosine and ceramide. J Biol Chem 1992;267:20044-20050.

9. Dobrowsky RT, Werner MH, Castellino AM, Chao MV, Hannun YA. Activation of the sphingomyelin cycle through the low-affinity neurotrophin receptor. Science 1994; 265: 1596-1599.

10. Haimovitz-Friedman A, Kan CC, Ehleiter D, et al. lonizing radiation acts on cellular membranes to generate ceramide and initiate apoptosis. J Exp Med 1994;180:525-535.

11. Okazaki T, Bell RM, Hannun YA. Sphingomyelin turnover induced by vitamin D3 in HL-60 cells. Role in cell differentiation. J Biol Chem 1989;264:19076-19080.

12. Testi R. Sphingomyelin breakdown and cell fate. Trends Biochem Sci 1996;21:468-471.

13. Kolesnick R, Golde DW. The sphingomyelin pathway in tumor necrosis factor and interleukin-1 signaling. Cell 1994; 77:325-328.

14. Divecha N, Irvine RF. Phospholipid signaling. Cell 1995; $80: 269-278$.

15. Santana P, Pena LA, Haimovitz-Friedman A, et al. Acid sphingomyelinase-deficient human lymphoblasts and mice are defective in radiation-induced apoptosis. Cell 1996;86: 189-199.

16. Dbaibo GS, Pushkareva MY, Jayadev S, et al. Retinoblastoma gene product as a downstream target for a ceramidedependent pathway of growth arrest. Proc Natl Acad Sci USA 1995;92:1347-1351.

17. Smyth MJ, Perry DK, Zhang J, Poirier GG, Hannun YA, Obeid LM. prICE: A downstream target for ceramide-induced apoptosis and for the inhibitory action of BCl-2. Biochem J 1996:316:25-28.

18. Raines MA, Kolesnick RN, Golde DW. Sphingomyelinase and ceramide activate mitogen-activated protein kinase in myeloid HL-60 cells. J Biol Chem 1993;268:14572-14575.

19. Machleidt T, Wiegmann K, Henkel T, Schutze S, Baeuerle P, Kronke M. Sphingomyelinase activates proteolytic I kappa B-alpha degradation in a cell-free system. J Biol Chem 1994; 269:13760-13765.

20. Zhang H, Buckley NE, Gibson K, Spiegel S. Sphingosine stimulates cellular proliferation via a protein kinase Cindependent pathway. J Biol Chem 1990;265:76-81.

21. Obeid LM, Linardic CM, Karolak LA, Hannun YA. Programmed cell death induced by ceramide. Science 1993; 259:1769-1771.

22. Jarvis WD, Kolesnick RN, Fornari FA, Traylor RS, Gewirtz DA, Grant S. Induction of apoptotic DNA damage and cell death by activation of the sphingomyelin pathway. Proc Natl Acad Sci USA 1994;91:73-77.

23. Kolesnick RN. Sphingomyelin and derivatives as cellular signals. Prog Lipid Res 1991;30:1-38.

24. Gatt S. Magnesium-dependent sphingomyelinase. Biochem Biophys Res Commun 1976;68:235-241.

25. Hostetler KY, Yazaki PJ. The subcellular localization of neutral sphingomyelinase in rat liver. J Lipid Res 1979;20: 456-463.

26. Spence MW. Sphingomyelinases. Adv Lipid Res 1993;26:323.

27. Merrill AH Jr, Hannun YA, Bell RM. Introduction: sphingolipids and their metabolites in cell regulation. Adv Lipid Res 1993;25:1-24.

28. Levade T, Salvayre R, Douste-Blazy L. Sphingomyelinases and Niemann-Pick disease. J Clin Chem Clin Biochem 1986; 24:205-220.

29. Nagata S. Apoptosis by death factor. Cell 1997;88:355365.

30. Brenner B, Ferlinz K, Grassme H, et al. Fas/CD95/Apo-I activates the acidic sphingomyelinase via caspases. Cell Death Differ 1998;5:29-37. 
31. Huang C, Ma W, Ding M, Bowden GT, Dong Z. Direct evidence for an important role of sphingomyelinase in ultraviolet-induced activation of c-Jun N-terminal kinase. J Biol Chem 1997;272:27753-27757.

32. Rehemtulla A, Hamilton CA, Chinnaiyan AM, Dixit VM. Ultraviolet radiation-induced apoptosis is mediated by activation of CD-95 (Fas/APO-1). J Biol Chem 1997;272: 25783-25786.

33. Sheikh MS, Antinore MJ, Huang $Y$, Fornace AJ Jr. Ultraviolet-irradiation-induced apoptosis is mediated via ligand independent activation of tumor necrosis factor receptor 1. Oncogene 1998;17:2555-2563.
34. Wiegmann K, Schutze S, Machleidt T, Witte D, Kronke M. Functional dichotomy of neutral and acidic sphingomyelinases in tumor necrosis factor signaling. Cell 1994;78: 1005-1015.

35. Keane MM, Ettenberg SA, Lowrey GA, Russell EK, Lipkowitz $S$. Fas expression and function in normal and malignant breast cell lines. Cancer Res 1996;56:47914798.

36. Wiegmann K, Schwandner R, Krut O, Yeh WC, Mak TW, Kronke M. Requirement of FADD for tumor necrosis factorinduced activation of acid sphingomyelinase. J Biol Chem 1999;274:5267-5270 